\title{
Synthesis, characterization, X-ray crystal structure, electrochemical evaluation and anti-cancer studies of a mixed ligand $\mathrm{Cu}$ (II) complex of (E)-N'-((2-hydroxynaphthalen-1-yl)methylene)acetohydrazide
}

\author{
IRAN SHEIKHSHOAIE ${ }^{\mathrm{a}}$, S YOUSEF EBRAHIMIPOUR ${ }^{\mathrm{a}, *}$, MAHDIEH SHEIKHSHOAIE ${ }^{\mathrm{a}}$, \\ MARYAM MOHAMADI ${ }^{\mathrm{a}, \mathrm{b}}$, MEHDI ABBASNEJAD ${ }^{\mathrm{c}}$, HADI AMIRI RUDBARI $^{\mathrm{d}}$ and \\ GIUSEPPE BRUNO \\ aDepartment of Chemistry, Faculty of Science, Shahid Bahonar University of Kerman, Kerman, Iran \\ ${ }^{b}$ Department of Chemistry, Payame Noor University (PNU), 19395-4697 Tehran, Iran \\ ${ }^{c}$ Department of Biology, Faculty of Sciences, Shahid Bahonar University of Kerman, Kerman, Iran \\ ${ }^{\mathrm{d}}$ Department of Chemistry, University of Isfahan, Isfahan 81746-73441, Iran \\ ${ }^{\text {e}}$ Department of Chemical Sciences, University of Messina, Via F. Stagno d'Alcontres 31, 98166 Messina, Italy \\ e-mail: Ebrahimipour@ymail.com; ebrahimipour@uk.ac.ir
}

MS received 25 May 2015; revised 7 September 2015; accepted 13 September 2015

\begin{abstract}
A ternary mixed ligand $\mathrm{Cu}(\mathrm{II})$ complex, $[\mathrm{Cu}(\mathrm{L})(\mathrm{Phen})]$, was prepared from the reaction of (E)$\mathrm{N}^{\prime}$-((2-hydroxynaphthalen-1-yl)methylene)acetohydrazide [HL], $\mathrm{Cu}\left(\mathrm{NO}_{3}\right)_{2} \cdot 3 \mathrm{H}_{2} \mathrm{O}$ and 1,10-Phenanthroline in 1:1:1 molar ratio. This complex was fully characterized using spectroscopic and physicochemical methods. The structure of the complex was determined by single crystal X-ray diffraction. The $\mathrm{Cu}(\mathrm{II})$ center is coordinated by two oxygen and one nitrogen donors of $\mathrm{L}^{2-}$ and nitrogen atoms of the heterocyclic group. Electrochemical studies of the $\mathrm{Cu}(\mathrm{II})$ complex showed shifts in the ligand peaks as well as the appearance of new peaks after complexation. The electrochemical behavior of the $\mathrm{Cu}$ (II) complex was also studied using cyclic voltammetry. According to biochemical investigation (MCF-7 cells viability), anticancer activity of $[\mathrm{Cu}(\mathrm{L})(\mathrm{Phen})]$ was higher than those of $\mathrm{Cu}\left(\mathrm{NO}_{3}\right)_{2} \cdot 3 \mathrm{H}_{2} \mathrm{O}$, $\mathrm{HL}$ and 1,10-Phenanthroline.
\end{abstract}

Keywords. Schiff base; $\mathrm{Cu}(\mathrm{II})$ complex; anticancer activity; electrochemical evaluation; crystal structure.

\section{Introduction}

In recent decades, hydrazone Schiff base ligands and their transition metal complexes have attracted much attention. ${ }^{1,2}$ To mention the reasons, we can point out their structural similarities with the biological units, facile synthesis and applications in several areas. A wide range of biological properties such as antibacterial, anti-fungal, ${ }^{3}$ anti-malarial, ${ }^{4}$ anti-cancer ${ }^{5}$ and other biochemical process ${ }^{6}$ have been reported for hydrazone derivatives. Among these, different applications of $\mathrm{Cu}$ (II) complexes are documented in various fields. ${ }^{7,8}$

Copper exists in the biological system as asymmetric multi-dentate chelates. ${ }^{9}$ The role of copper in both the etiology and growth of tumors has been extensively studied. ${ }^{10}$ Also many of the $\mathrm{Cu}(\mathrm{II})$ Schiff base complexes can be good models for simulating and representing their function and providing models for the metal-containing sites in copper-containing proteins and enzymes such as ascorbic oxidase. ${ }^{11}$

\footnotetext{
*For correspondence
}

In spite of the rapid development of novel anticancer drugs, outbreak of drug resistance and undesirable side effects have created many problems in cancer therapy. Thus, it is necessary to identify new compounds with improved properties in this regard. ${ }^{12}$

One of the characteristics of metal ions is their potential to undergo redox processes, as determined by their redox potentials. Especially, transition metal ions are usually able to switch between several oxidation states. Due to the redox activity of metals and, therefore, a possible disturbance of the sensitive cellular redox homeostasis, a tight regulation of the metal and redox balance is crucial for health and survival. ${ }^{10,13,14}$

Copper has a crucial role in redox reactions and triggers generation of reactive oxygen species (ROS) in human cells. $\mathrm{Cu}(\mathrm{II})$ complexes are well known for their redox activity, which seems to be, at least in part, involved in the most of their defined biological activities. ${ }^{15-18}$

Herein, we describe the synthesis, characterization of a new mixed-ligand $\mathrm{Cu}$ (II) complex. Furthermore, the effects of the synthesized compounds on the 
anti-cancer viability of breast cancer cells are investigated and described.

\section{Experimental}

\subsection{Materials and instrumentation}

All chemicals and solvents were of analytical reagent grade and used as received. Ligand HL was prepared according to previous report. ${ }^{5}$ Melting points were determined with the help of an Electrothermal Apparatus-9200. Elemental analyses were carried out using a Thermo Finnigan Flash Elemental Analyzer 1112EA. FT-IR spectra were recorded at a Bruker-Tensor 27 by embedding the material in $\mathrm{KBr}$ discs in the range of $400-4000 \mathrm{~cm}^{-1}$. Molar Conductance measurements were made by means of a Metrohm 712 Conductometer in DMSO. Electronic spectra were recorded at $2{ }^{\circ} \mathrm{C}$ using a Cary 50 UV-Vis spectrophotometer. ${ }^{1} \mathrm{H}-\mathrm{NMR}$ spectrum was recorded at $25^{\circ} \mathrm{C}$ on an Avance BRX $400 \mathrm{MHz}$ spectrometer. All electrochemical experiments were performed on a Sama 500 electrochemical analyzer (Iran) at room temperature in DMSO solution with $0.1 \mathrm{M}$ tetrabutylammonium bromide as the supporting electrolyte. An $\mathrm{Ag} / \mathrm{AgCl}$ (saturated $\mathrm{KCl}$ )/3 $\mathrm{M} \mathrm{KCl}$ reference electrode, a Pt wire as counter electrode and a glassy carbon electrode as working electrode were employed for the electrochemical studies. Cell culture reagents, penicillin-streptomycin solution, trypsin EDTA, and fetal bovine serum (FBS) were obtained from Biosera CO. (East Sussex, UK). Culture flasks and dishes were acquired from SPL lifesciences Inc. (Gyeonggi-Do, South Korea). 3-[4,5]-Dimethyl2-thiazolyl-2,5-diphenyl-2-tetrazolium bromide (MTT) was purchased from Sigma (St. Louis, MI, USA).

\subsection{Synthesis of (E)-N'-((2-hydroxynaphthalen-1-yl) methylene)acetohydrazide [HL]}

A $5 \mathrm{~mL}$ ethanolic solution of 2-hydroxy naphtaldehyde $(2 \mathrm{mmol}, 0.2 \mathrm{~g})$ was added to an ethanolic solution $(4 \mathrm{~mL})$ of acetohydrazide $(2 \mathrm{mmol}, 0.30 \mathrm{~g})$. The mixture was stirred for $10 \mathrm{~min}$ at $50^{\circ} \mathrm{C}$. The resulting precipitate was filtered off, washed with cold ethanol and dried in desiccator over silica gel. Yield: $0.51 \mathrm{~g}, 86 \%$. M.p.: $211^{\circ} \mathrm{C}$. FT-IR (KBr), $\mathrm{cm}^{-1}: v(\mathrm{OH}) 3185, v(\mathrm{NH})$ 3012, $v(\mathrm{C}=\mathrm{O}) 1678, v(\mathrm{C}=\mathrm{N}) 1642, v\left(\mathrm{C}=\mathrm{C}_{\text {ring }}\right) 1467$, $v(\mathrm{C}-\mathrm{O}) 1286, v(\mathrm{NN}) 1126, \delta_{\text {oopb }}(\mathrm{OH}) 720 .{ }^{1} \mathrm{H}-\mathrm{NMR}$ (400 MHz, DMSO- $\left.d_{6}, 25^{\circ} \mathrm{C}, \mathrm{ppm}\right): \delta=12.61(\mathrm{~s}, 1 \mathrm{H}$, $-\mathrm{OH}), 11.74(\mathrm{~s}, 1 \mathrm{H}, \mathrm{NH}), 9.14(\mathrm{~s}, 1 \mathrm{H},-\mathrm{CH}=\mathrm{N}), 8.21-$ $7.22(\mathrm{~m}, 6 \mathrm{H}, \mathrm{ArH}), 2.02\left(\mathrm{~s}, 3 \mathrm{H},-\mathrm{CH}_{3}\right)$. UV/Vis (DMSO) $\lambda_{\max }, \mathrm{nm}\left(\varepsilon, \mathrm{L} \mathrm{mol}^{-1} \mathrm{~cm}^{-1}\right): 315$ (12022), 323 (14454), 360 (12882), 371 (12303), 417 (1513).
2.3 Preparation of (1,10-phenanthroline)(E)-1-((2acetylhydrazono)methyl)naphthalen-2-olate copper(II) [Cu(L)(Phen)]

$\mathrm{Cu}\left(\mathrm{NO}_{3}\right)_{2} \cdot 2 \mathrm{H}_{2} \mathrm{O}(0.1 \mathrm{mmol}, 0.0223 \mathrm{~g})$ was added to a solution of HL $(0.1 \mathrm{mmol}, 0.0228 \mathrm{~g})$ in $5 \mathrm{~mL}$ of boiling ethanol and the mixture was refluxed in a water bath for $10 \mathrm{~min}$. 1,10-Phenanthroline $(0.1 \mathrm{mmol}, 0.0180 \mathrm{~g})$ was added to the resulting dark-green colored solution which was further refluxed for $c a$. $1 \mathrm{~h}$. After cooling, the precipitate was separated and then recrystallized from methanol to give green single crystal and were dried in a vacuum desiccator over $\mathrm{CaCl}_{2}$. Yield: $0.030 \mathrm{~g}$, 64\%. M.p.:260 ${ }^{\circ}$ C. Anal. Calc. (\%) for $\mathrm{C}_{25} \mathrm{H}_{18} \mathrm{CuN}_{4} \mathrm{O}_{2}$ (469.98 $\left.\mathrm{g} \mathrm{mol}^{-1}\right)$ : C, 63.89; H, 3.86; N, 11.92. Found (\%): C, 63.82; H, 3.79; N, 11.94\%. Molar conductance $\left(10^{-3} \mathrm{M}\right.$, DMSO) $7.1 \mathrm{ohm}^{-1} \mathrm{~cm}^{2} \mathrm{~mol}^{-1}$. FT-IR $(\mathrm{KBr}), \mathrm{cm}^{-1}: v(\mathrm{C}=\mathrm{N}) 1621, v\left(\mathrm{C}=\mathrm{C}_{\text {ring }}\right) 1465, v(\mathrm{C}-$ O) $1241, v(\mathrm{~N}-\mathrm{N}) 1141$. UV/Vis (DMSO, $\lambda_{\max }, \mathrm{nm}(\varepsilon$, $\left.\mathrm{L} \mathrm{mol}{ }^{-1} \mathrm{~cm}^{-1}\right)$ : 265(43651), 335(9332), 395(14125), 415(17782), 435(13490), 648(158).

\subsection{Crystal structure determination}

X-ray data for $[\mathrm{Cu}(\mathrm{L})(\mathrm{Phen})]$ was collected at room temperature with a Bruker APEX II CCD area-detector diffractometer using Mo $\mathrm{K} \alpha$ radiation $(\lambda=0.71073 \AA)$. Data collection, cell refinement, data reduction and absorption correction were performed using multiscan methods with Bruker software. ${ }^{19}$ The structures were solved by direct methods using SIR2004. ${ }^{20}$ The nonhydrogen atoms were refined anisotropically by the full matrix least squares method on $F^{2}$ using SHELXL. ${ }^{21}$ All the hydrogen $(\mathrm{H})$ atoms were placed at calculated positions and constrained to ride on their parent atoms. Details concerning collection and analysis are reported in table 1.

\subsection{Cell culture}

MCF-7 (breast cancer) cells were obtained from National Cell Bank of Iran (NCBI)-Pasteur Institute of Iran (Tehran, Iran). Cells were grown with Dulbecco's modified Eagle's medium supplemented with $10 \%$ fetal bovine serum, penicillin $(100 \mathrm{U} / \mathrm{mL})$ and streptomycin $(100 \mathrm{~g} / \mathrm{mL})$. They were maintained at $37^{\circ} \mathrm{C}$ in a $5 \%$ $\mathrm{CO}_{2}$ atmosphere. Growth medium was changed three times a week. Cells were plated at the density of 5000 per well in a 96 micro plate well for the MTT assay. The cells were incubated with different doses of compounds. MCF-7 cells are useful for in vitro breast cancer studies because they have retained several 
Table 1. Crystal data and structure refinement for $[\mathrm{Cu}(\mathrm{L})(\mathrm{phen})]$.

\begin{tabular}{|c|c|c|}
\hline Empirical formula & $\mathrm{C}_{25} \mathrm{H}_{18} \mathrm{Cu} \mathrm{N}_{4} \mathrm{O}_{2}$ & \\
\hline Formula weight & 469.97 & \\
\hline Temperature & 296(2) K & \\
\hline Wavelength & $0.71073 \AA$ & \\
\hline Crystal system, space group & Monoclinic, $C 2 / c$ & \\
\hline Unit cell dimensions & $a=25.1157(11) \AA$ & $\begin{array}{c}\alpha=90^{\circ} \\
\alpha\end{array}$ \\
\hline & $\begin{array}{l}b=11.2432(4) \AA \\
c=15.2228(5) \AA\end{array}$ & $\begin{array}{c}\beta=94.727(3) \\
\gamma=90^{\circ}\end{array}$ \\
\hline Volume & $4284.0(3) \mathrm{A}^{3}$ & \\
\hline Z, Calculated density & $8,1.457 \mathrm{Mg} / \mathrm{m}^{3}$ & \\
\hline Absorption coefficient & $1.050 \mathrm{~mm}^{-1}$ & \\
\hline$F(000)$ & 1928 & \\
\hline Theta range for data collection & 3.2 to $27.00^{\circ}$. & \\
\hline Limiting indices & $\begin{array}{c}-32<=\mathrm{h}<=32,-14<=\mathrm{k}<=14 \\
-19<=\mathrm{l}<=19\end{array}$ & \\
\hline Reflections collected / unique & $39718 / 4620[\mathrm{R}(\mathrm{int})=0.0294]$ & \\
\hline Completeness to theta & $27.00(98.6 \%)$ & \\
\hline Refinement method & Full-matrix least-squares on $F^{2}$ & \\
\hline Data / restraints / parameters & 4620 / 0 / 290 & \\
\hline Goodness-of-fit on $\mathrm{F}^{2}$ & 0.927 & \\
\hline Final R indices $[\mathrm{I}>2 \sigma(\mathrm{I})]$ & $\mathrm{R}_{1}=0.0292, \mathrm{wR}_{2}=0.0782$ & \\
\hline $\mathrm{R}$ indices (all data) & $\mathrm{R}_{1}=0.0402, \mathrm{wR}_{2}=0.0882$ & \\
\hline Largest diff. peak and hole & 0.299 and $-0.220 \mathrm{e}^{-\mathrm{A}^{-3}}$ & \\
\hline
\end{tabular}

characteristics of mammary epithelium. MCF-7 cell line is an estrogen receptor (ER) positive cell line. ${ }^{22}$

\subsection{MTT assay}

Cellular viability was assessed by the reduction of 2-(4, 5-dimethylthiazol-2-yl)-2,5-diphenyltetrazolium bromide (MTT) to Formazan. The reduction of tetrazolium salts is now widely accepted as a reliable way to examine cell proliferation. The yellow tetrazolium MTT $(3-(4,5-$ dimethylthiazolyl-2)-2,5-diphenyltetrazolium bromide) is reduced by metabolically active cells, in part by the action of dehydrogenase enzymes, to generate reducing equivalents such as NADH and NADPH. The resulting intracellular purple Formazan can be solubilized and quantified by spectrophotometric means. ${ }^{23}$ MTT was dissolved in PBS, and added to the culture at final concentration of $0.5 \mathrm{mg} / \mathrm{ml}$. After additional $2 \mathrm{~h}$ incubation at $37^{\circ} \mathrm{C}$, the media were carefully removed and $100 \mu \mathrm{L}$ DMSO was added to each well, and the absorbance (OD) values were determined at $490 \mathrm{~nm}$ with microplate reader (BioTek ELX808). Results were expressed as percentages of control. ${ }^{5}$

\subsection{Statistical analysis}

The results are expressed as mean \pm SEM. The differences in cell viability (mean MTT assay) between groups were determined by one-way ANOVA, followed by the Tukey test. $\mathrm{P}<0.05$ was considered significant.

\section{Result and Discussion}

A ternary $\mathrm{Cu}(\mathrm{II})$ complex containing ONO hydrazine ligand ( $\mathrm{HL}), \mathrm{Cu}\left(\mathrm{NO}_{3}\right)_{2} \cdot 2 \mathrm{H}_{2} \mathrm{O}$ and 1,10-Phenanthroline in molar ratio 1:1:1 has been prepared. The complex is stable in air and soluble in most organic solvent except $n$-hexane and diethyl ether.

\subsection{FT-IR study}

In the FT-IR spectrum of HL, the bands observed at 3012 and $720 \mathrm{~cm}^{-1}$ are respectively associated to stretching and out of plane bending vibrations of $\mathrm{OH}^{5}$ and $\mathrm{NH}$ stretching vibration in $\mathrm{HL}$ is located at $3012 \mathrm{~cm}^{-1} \cdot{ }^{24}$ Disappearance of these bands in the spectrum of the complex is strong evidence for complexation. Coordination of nitrogen of the azomethine group results in a red shift of $\mathrm{CN}$ vibration from $1642 \mathrm{~cm}^{-1}$ to $1621 \mathrm{~cm}^{-1} .^{25} \mathrm{~A} 45 \mathrm{~cm}^{-1}$ red shift is observed in the stretching vibration of $\mathrm{CO}$ of the complex relative to that of the free ligand, consistent with the coordination of the Schiff base ligand with the $\mathrm{Cu}$ (II) central ion through the phenolic oxygen. ${ }^{26}$ The IR spectrum of the complex reveals stretching vibrations of $\mathrm{Cu}-\mathrm{O}$ and $\mathrm{Cu}-\mathrm{N}$ at 650 and $525 \mathrm{~cm}^{-1}$, respectively. ${ }^{3}$

\subsection{Electronic spectra}

Electronic spectra of compounds were recorded in DMSO. In the UV-Vis spectrum of the Schiff base 


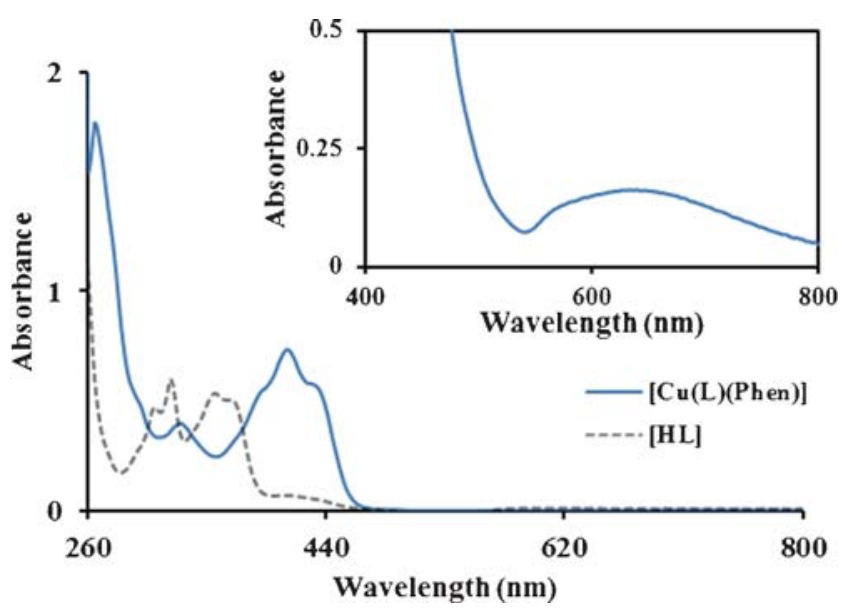

Figure 1. Electronic spectra of HL $\left(3 \times 10^{-5} \mathrm{M}\right)$ and its $\mathrm{Cu}$ (II) complex $\left(3 \times 10^{-5} \mathrm{M}\right)$ in DMSO. The $d-d$ transition $\left(10^{-3} \mathrm{M}\right)$ is shown in inset for the complex.

ligand $[\mathrm{HL}], \pi \rightarrow \pi^{*}$ transitions of the aromatic rings and $\pi \rightarrow \pi^{*}$ and $n \rightarrow \pi^{*}$ transitions of the carbonyl moiety and imine bonds were appeared as five absorption bands in the range of $315-417 \mathrm{~nm}$ (figure 1). ${ }^{5}$ Similar features were observed in the spectrum of $[\mathrm{Cu}(\mathrm{L})(\mathrm{Phen})]$. Appearance of two peaks at 415 and $435 \mathrm{~nm}$ with epsilon values of $\log \varepsilon\left(\mathrm{M}^{-1} \mathrm{~cm}^{-1}\right)=4.25$ and 4.16, respectively, confirmed coordination of the ligand to the metal center. These high epsilon values indicate that the corresponding peaks were originated from MLCT (metal to ligand) and LMCT (ligand to metal) charge transfer transitions. In five-coordinated $\mathrm{Cu}$ (II) complexes, the electronic spectrum in visible region can be used for predicting the preferred geometry (SP or TBP). It has been demonstrated that presence of a peak in $550-660 \mathrm{~nm}$ range which is related to $d_{x z}$, $\mathrm{d}_{\mathrm{yz}} \rightarrow \mathrm{d}_{\mathrm{x}}^{2}-_{\mathrm{y}}^{2}$ shows $\mathrm{SP}$ or distorted SP geometries. ${ }^{27,28}$ For example, $\mathrm{Cu}$ (TMCPMP-TS)(Phen)] complex synthesized by Vyas and coworkers showed a peak in the 670-690 nm range resulted in SP geometry which was confirmed by other characterization techniques including X-ray crystal structure. ${ }^{29}$ On the other hand, TBP structures exhibit a characteristic peak around $>800 \mathrm{~nm}$ that is assigned to $\mathrm{d}_{\mathrm{xz}}, \mathrm{d}_{\mathrm{x}}{ }^{2}-{ }_{\mathrm{y}}{ }^{2} \rightarrow \mathrm{d}_{\mathrm{z}}{ }^{2} \cdot{ }^{30}$ In the visible spectrum of $[\mathrm{Cu}(\mathrm{L})(\mathrm{Phen})]$, a band was observed at $648 \mathrm{~nm}$ (figure 1). Accordingly, the geometry of the $\mathrm{Cu}(\mathrm{II})$ complex synthesized here is closer to $\mathrm{SP}^{3}$

\subsection{X-ray Crystal Structure}

The title complex, $[\mathrm{Cu}(\mathrm{L})(\mathrm{Phen})]$ consists of a $\mathrm{Cu}(\mathrm{II})$ ion coordinated by an deprotonated dianionic tridentate ONO schiff base ligand (E)-1-((2-acetylhydrazono) methyl)naphthalen-2-olate $\left(\mathrm{L}^{2-}\right)$ and one bidentate 1,10 phenanthroline ligand. An ORTEP view of the asymmetric unit of $[\mathrm{Cu}(\mathrm{L})(\mathrm{Phen})]$ is shown in figure 2 . Selected bond lengths and angles for the $\mathrm{Cu}(\mathrm{II}) \mathrm{com}-$ plex are set out in table 2 .

$\mathrm{The} \mathrm{Cu}(\mathrm{II})$ ion is situated in a distorted square pyramidal environment $\left(\mathrm{N}_{3} \mathrm{O}_{2}\right.$ chromophore $)$ with trigonality index $\tau=0.21(\tau=(\beta-\alpha) / 60$ where $\beta$ and $\alpha$ are the two largest bond angles around the metal center in five coordinated environment. for ideal square pyramid, $\tau$ is 0 but this value for ideal trigonal-bipyramidal

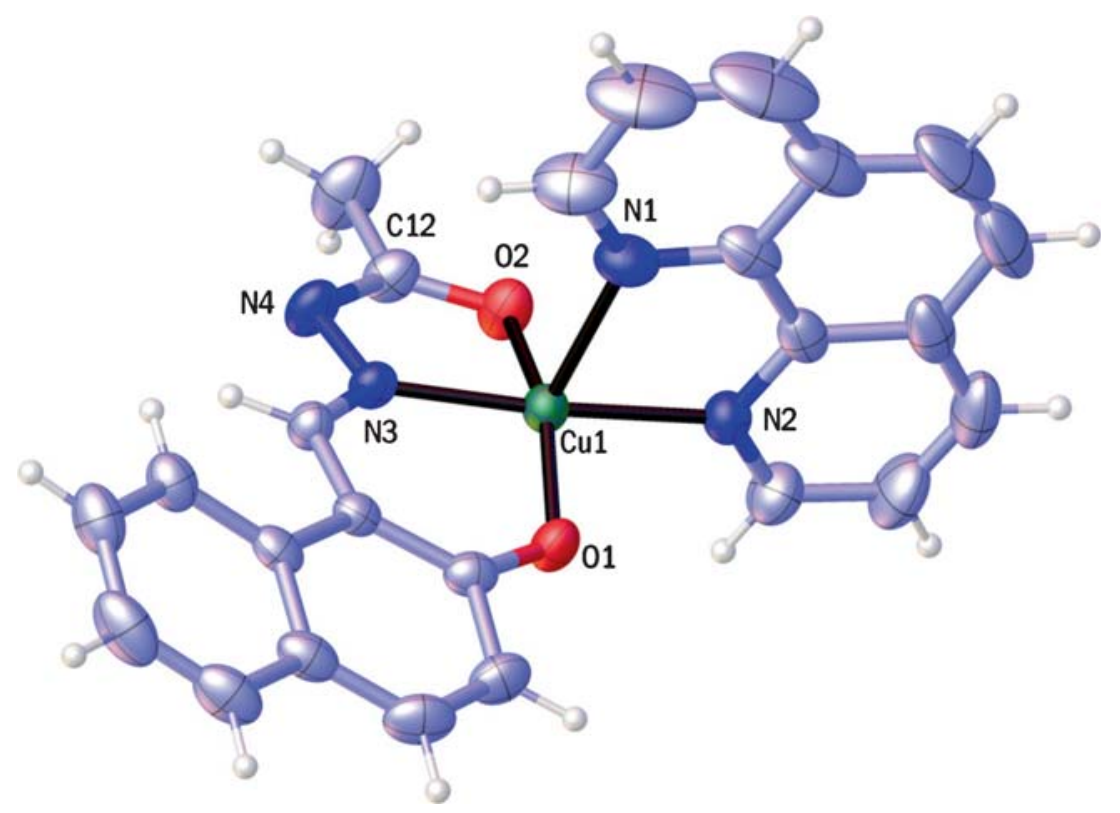

Figure 2. ORTEP view of $[\mathrm{Cu}(\mathrm{L})(\mathrm{Phen})]$. Non-H atoms, represented as displacement ellipsoids, are plotted at the $50 \%$ probability level, while $\mathrm{H}$ atoms are shown as small spheres of arbitrary radius. 
Table 2. Bond lengths $[\AA]$ and angles $\left[^{\circ}\right]$ for $[\mathrm{Cu}(\mathrm{L})(\mathrm{phen})]$.

\begin{tabular}{ll}
$\mathrm{O}(2)-\mathrm{Cu}(1)$ & $1.9466(14)$ \\
$\mathrm{Cu}(1)-\mathrm{N}(3)$ & $1.9095(15)$ \\
$\mathrm{Cu}(1)-\mathrm{O}(1)$ & $1.9161(13)$ \\
$\mathrm{Cu}(1)-\mathrm{N}(2)$ & $2.0280(16)$ \\
$\mathrm{Cu}(1)-\mathrm{N}(1)$ & $2.2366(17)$ \\
$\mathrm{N}(4)-\mathrm{N}(3)$ & $1.403(2)$ \\
$\mathrm{N}(3)-\mathrm{Cu}(1)-\mathrm{O}(1)$ & $92.30(6)$ \\
$\mathrm{N}(3)-\mathrm{Cu}(1)-\mathrm{O}(2)$ & $81.45(6)$ \\
$\mathrm{O}(1)-\mathrm{Cu}(1)-\mathrm{O}(2)$ & $161.08(6)$ \\
$\mathrm{N}(3)-\mathrm{Cu}(1)-\mathrm{N}(2)$ & $173.78(6)$ \\
$\mathrm{O}(1)-\mathrm{Cu}(1)-\mathrm{N}(2)$ & $93.92(6)$ \\
$\mathrm{O}(2)-\mathrm{Cu}(1)-\mathrm{N}(2)$ & $92.55(6)$ \\
$\mathrm{N}(3)-\mathrm{Cu}(1)-\mathrm{N}(1)$ & $100.71(7)$ \\
$\mathrm{O}(1)-\mathrm{Cu}(1)-\mathrm{N}(1)$ & $99.95(6)$ \\
$\mathrm{O}(2)-\mathrm{Cu}(1)-\mathrm{N}(1)$ & $98.75(7)$ \\
$\mathrm{N}(2)-\mathrm{Cu}(1)-\mathrm{N}(1)$ & $78.45(7)$ \\
\hline
\end{tabular}

structure is equal to 1$){ }^{31}$ The square plane is made up of enolate oxygen atom $(\mathrm{O} 2)$, the phenolate oxygen atom (O1), and the imine nitrogen atom (N3) of dianionic tridentate ligand. The fourth site is occupied by nitrogen atom of the hetrocyclic ligand (N2). The other nitrogen atom of 1,10 phenantroline (N1) occupies the axial position.

The $\mathrm{Cu}-\mathrm{O} 1, \mathrm{Cu}-\mathrm{O} 2, \mathrm{Cu}-\mathrm{N} 2$ and $\mathrm{Cu}-\mathrm{N} 3$ bond distances are 1.9161(13), 1.9466(14), 1.9095(15) and $2.0280(16) \AA$, respectively which are similar to those values in similar reported structures. The unit cell and Crystal packing representation for title complex are shown in figure 3 . As shown in this figure, the short contact (van der Walls interactions) stabilizes the crystal structure of this compound.

\subsection{Electrochemical studies}

The electrochemical behavior of the ligand and its $\mathrm{Cu}(\mathrm{II})$ complex $\left(10^{-3} \mathrm{M}\right)$ were evaluated using cyclic voltammetry in DMSO containing 0.1 M TBAB as supporting electrolyte. Cyclic voltammograms of the ligand and its $\mathrm{Cu}$ (II) complex are depicted in figure 4 . The free ligand exhibits a quasi-reversible electrochemical behavior (oxidation wave at $\sim 0.58 \mathrm{~V}$ and reduction wave at $\sim 0.33 \mathrm{~V})$. With increasing the potential scan rate, the oxidation peak shifted slightly towards more positive potentials while the reduction one shifted towards more negative potentials, as expected for a quasi-reversible electron transfer process.

In the voltammogram of the complex, a redox couple at $0.10 \mathrm{~V}$ and $0.065 \mathrm{~V}$ with the peak currents of 1.56 and $2.58 \mu \mathrm{A}$, respectively were observed which can be assigned to $\mathrm{Cu}^{\mathrm{II} / \mathrm{I}} \cdot 32,33$ Once again, increasing the potential scan rate shifted the first peak (oxidation) towards more positive potentials and shifted the second one (reduction) towards more negative potentials.

\subsection{Anticancer activity}

Breast cancer cells (MCF-7 cell line) were selected to investigate the anticancer activity of the synthesized compounds. The cancer cells were treated with different concentrations of $\mathrm{Cu}\left(\mathrm{NO}_{3}\right)_{2} .3 \mathrm{H}_{2} \mathrm{O}$, [HL], 1,10-phenanthroline and $[\mathrm{Cu}(\mathrm{L})($ Phen $)](0,1,5,10$ and $20 \mu \mathrm{M})$ for $24 \mathrm{~h}$. The obtained results are depicted in figure 5. As expected, the cell viability decreases with increasing the concentration of each compound in a dose-dependent manner.

Generally, cytotoxic effect of the complex is more than those of the other tested compounds. It has been reported that 1,10-phenanthroline derivatives has potent cytotoxicity against various cancer cell lines and can induce apoptosis. ${ }^{34}$ In addition, hydrazone derivatives elicit potent toxic effect on cancer cells. ${ }^{35}$ It is clear that the anticancer activity of the synthesized $\mathrm{Cu}$ (II) complex here has been significantly improved compared
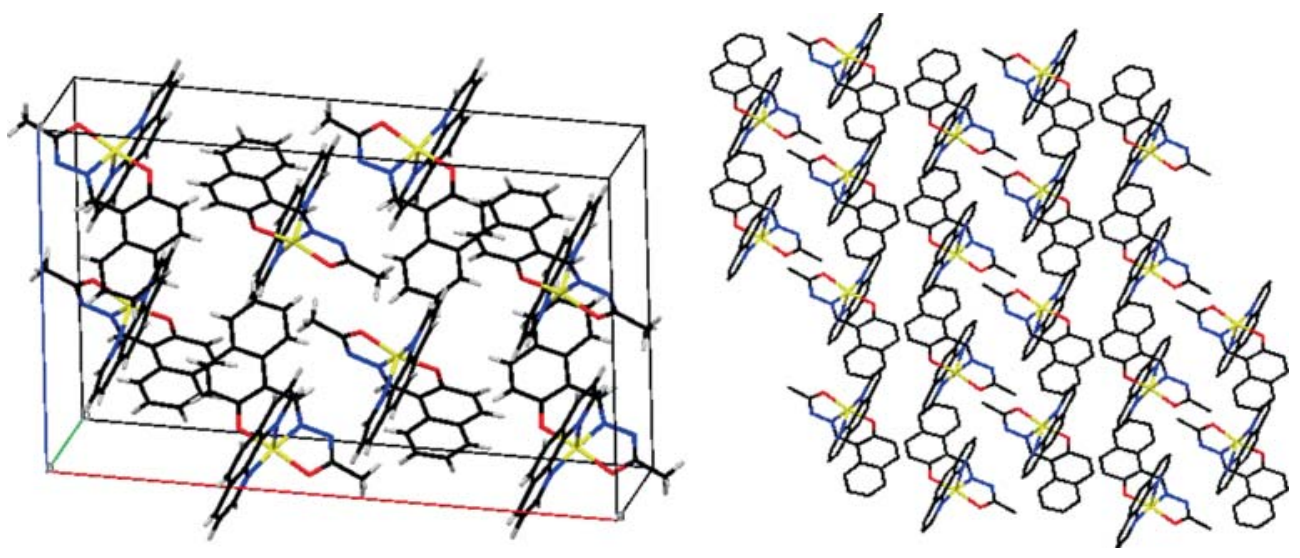

Figure 3. Unit cell of the complex $[\mathrm{Cu}(\mathrm{L})(\mathrm{Phen})]$ (left) and illustration of p-stacking interaction in $\mathrm{Cu}(\mathrm{II})$ complex with hydrogen omitted for clarity (right). 


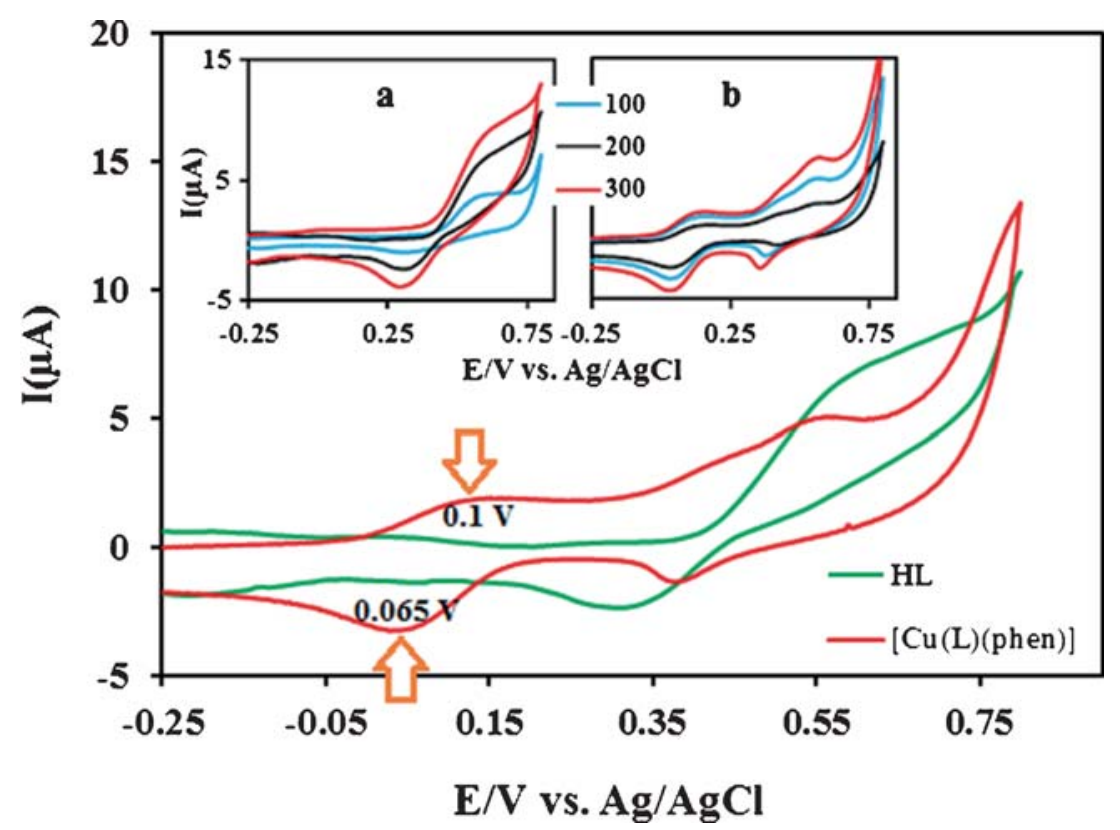

Figure 4. A comparison between cyclic voltammograms of the ligand and the $\mathrm{Cu}$ (II) complex at a scan rate of $200 \mathrm{mV} / \mathrm{s}$. $(\mathrm{Ag} / \mathrm{AgCl}$ (saturated $\mathrm{KCl}) / 3 \mathrm{M}$ $\mathrm{KCl}$ was used as reference electrode). Cyclic voltammograms of the [HL] (inset a) and its $\mathrm{Cu}$ (II) complex (inset b) at scan rates of 100, 200 and $300 \mathrm{mV} / \mathrm{s}$.

with the parent Schiff base ligand [HL] and the hetrocyclic ligand 1,10-phenanthroline and also the metal salt.

It has been documented that copper complexes of 1,10-phenanthroline can intercalate into the DNA minor grooves. This interaction enables redox reactions of the $\mathrm{Cu}(\mathrm{II})$ core with DNA and even RNA. ${ }^{36,37}$

Metal complexes have been proposed to trigger apoptosis pathway leading to cytochrome $\mathrm{c}$ release and

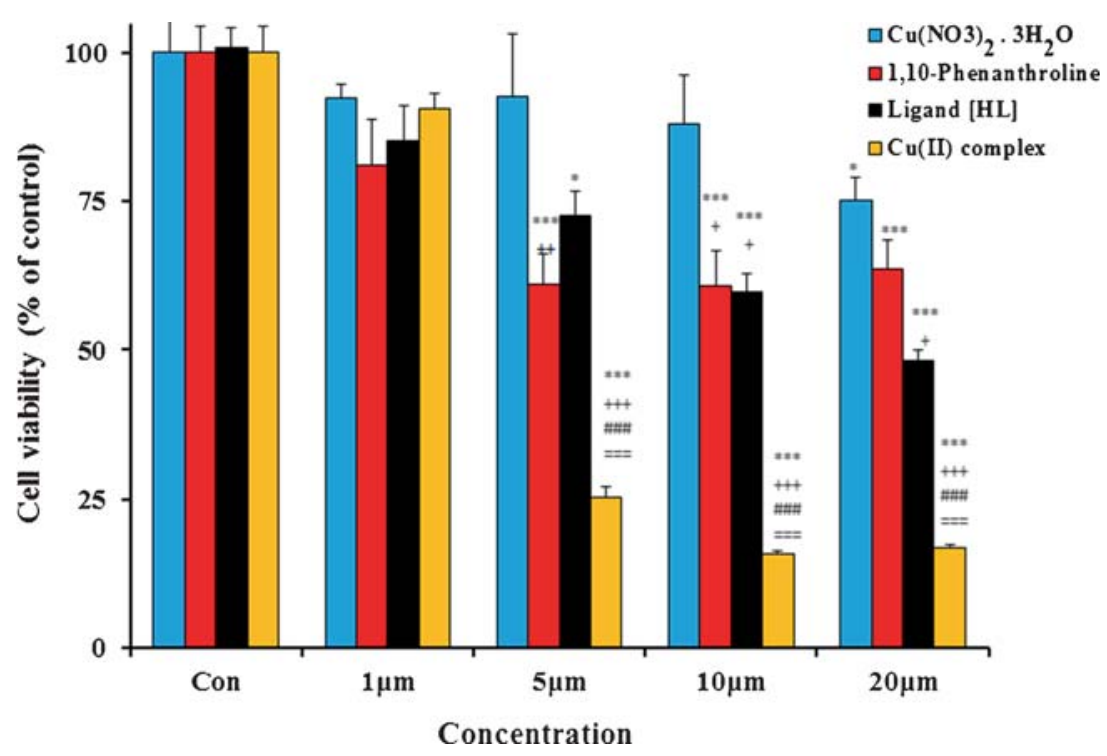

Figure 5. Effects of different doses of $\mathrm{Cu}\left(\mathrm{NO}_{3}\right)_{2} .3 \mathrm{H}_{2} \mathrm{O}$, [HL], 1,10Phenanthroline and $[\mathrm{Cu}(\mathrm{L})(\mathrm{Phen})]$ on MCF-7 cancer cells viability determined by MTT assay. The components have dose dependent toxic effect on cancer cells. Data are expressed as mean \pm SEM; $n=6$ well for each group; $* \mathrm{p}<0.05,{ }^{*} \mathrm{P}<0.01$ and $* * * \mathrm{p}<0.001$ versus control (non-treated) cells; $+\mathrm{p}$ $<0.05,++\mathrm{P}<0.01$ and $+++\mathrm{p}<0.001$ versus $\mathrm{Cu}\left(\mathrm{NO}_{3}\right)_{2} .3 \mathrm{H}_{2} \mathrm{O}$-treated cells; \#P $<0.05 ; \# \# \#$ P $<0.001$ versus $1,10-$ Phenanthroline-treated cells and $===\mathrm{P}<0.001$ versus $[\mathrm{HL}]$-treated cells in same doses. 
caspase-3 activation. ${ }^{38}$ Apoptosis is a multi-step and multi-pathway programmed cell death that is inherent in all cells. Cancer treatment by chemotherapy and irradiation primarily kills target cells through apoptosis.

$\mathrm{IC}_{50}$ value for the complex against MCF-7 cell line was calculated to be $2.4 \mu \mathrm{M}$ which was significantly smaller than that reported for the well-known anticancer drug, cis-platin. ${ }^{39,40} \mathrm{IC}_{50}$ value for $\mathrm{HL}$ was found to be $17.4 \mu \mathrm{M}$. So, the $[\mathrm{Cu}(\mathrm{L})(\mathrm{Phen})]$ synthesized here can be proposed as an efficient anti-cancer agent alternative for cis-platin. However, further studies are needed to investigate all aspects of treatment by this drug.

\section{Conclusions}

A new ternary mixed-ligand copper(II) complex, $[\mathrm{Cu}$ (L)(Phen)] was synthesized and structurally characterized. Single crystal X-ray diffraction analysis revealed that this complex has square pyramidal geometry around $\mathrm{Cu}$ (II) center and positions around it are occupied with the oxygen and nitrogen atoms of [HL] and nitrogen atoms of 1,10-Phenanthroline. Anti-cancer activities of [HL], $\mathrm{Cu}\left(\mathrm{NO}_{3}\right)_{2} .3 \mathrm{H}_{2} \mathrm{O}, 1,10$-phenanthroline and $[\mathrm{Cu}(\mathrm{L})$ (Phen)] against human breast cancer cells (MCF-7) were investigated and compared with each other. It was found that $[\mathrm{Cu}(\mathrm{L})(\mathrm{Phen})]$ complex showed higher anticancer activity than the others.

\section{Supplementary Information}

FT-IR spectra of $[\mathrm{HL}]$ and $[\mathrm{Cu}(\mathrm{L})(\mathrm{Phen})],{ }^{1} \mathrm{H}$ NMR spectrum of ligand, atomic coordinates and equivalent isotropic displacement parameters, bond lengths and angles, and anisotropic displacement parameters for $[\mathrm{Cu}(\mathrm{L})(\mathrm{Phen})]$ are available at www.ias.ac.in/chemsci. CCDC 1043607 contains the supplementary crystallographic data for $[\mathrm{Cu}(\mathrm{L})(\mathrm{phen})]$. A copy of this information may be obtained free of charge from The Director, CCDC, 12 Union Road, Cambridge, Cb2 1EZ, UK (fax: +44 1223336 033); web page: http://www.ccdc.cam. ac.uk/cgibin/catreq.cgi

\section{References}

1. Ebrahimipour $\mathrm{S} \mathrm{Y}$, Khabazadeh $\mathrm{H}$, Castro $\mathrm{J}$, Sheikhshoaie I, Crochet A and Fromm K M 2015 Inorg. Chim. Acta 42752

2. Chang H Q, Jia L, Xu J, Xu Z Q, Chen R H, Wu W N, Bie H Y, Zhu T F, Ma T L and Wang Y 2015 Inorg. Chem. Commun. 578
3. Ebrahimipour S Y, Sheikhshoaie I, Crochet A, Khaleghi M and Fromm K M 2014 J. Mol. Struct. 1072267

4. Verma G, Marella A, Shaquiquzzaman M, Akhtar M, Ali M R and Alam M M 2014 J. Pharm. Bioallied Sci. 6 69

5. Ebrahimipour S Y, Sheikhshoaie I, Castro J, Haase W, Mohamadi M, Foro S, Sheikhshoaie M and EsmaeiliMahani S 2015 Inorg. Chim. Acta 430245

6. Ebrahimipour S Y, Sheikhshoaie I, Mohamadi M, Suarez S, Baggio R, Khaleghi M, Torkzadeh-Mahani M and Mostafavi A 2015 Spectrochim. Acta A 142410

7. Collman J P, Zhong M, Zhang C and Costanzo S 2001 J. Org. Chem. 667892

8. Narani A, Marella R K, Ramudu P, Rao K S R and Burri D R 2014 RSC Adv. 43774

9. Crichton R 2007 In Biological Inorganic Chemistry: An Introduction (Amsterdam: Elsevier)

10. Gupte A and Mumper R J 2009 Cancer Treat. Rev. 3532

11. Moradi-Shoeili Z, Amini Z, Boghaei D M and Notash B 2013 Polyhedron $\mathbf{5 3} 76$

12. Vogel H G 2008 In Drug Discovery and Evaluation: Pharmacological Assays (Berlin: Springer)

13. Arredondo M and Núñez M T 2005 Mol. Aspects Med. 26313

14. Balamurugan K and Schaffner W 2006 Biochim. Biophys. Acta 1763737

15. Antholine W E and Taketa F 1984 J. Inorg. Biochem. 20 69

16. Byrnes R W, Mohan M, Antholine W E, Xu R X and Petering D H 1990 Biochemistry 297046

17. Chikira M, Tomizawa Y, Fukita D, Sugizaki T, Sugawara N, Yamazaki T, Sasano A, Shindo H, Palaniandavar M and Antholine W E 2002 J. Inorg. Biochem. 89163

18. Narasimhan J, Antholine W E, Chitambar C R and Petering D H 1991 Arch. Biochem. Biophys. 289393

19. (a) COSMO, Version 1.602005 (Madison WI: Bruker AXS Inc.); (b) SAINT, Version 7.06A 2005 (Madison WI: Bruker AXS Inc.); (c) SADABS, Version 2.10 2005 (Madison WI: Bruker AXS Inc.)

20. Burla M C, Caliandro R, Carrozzini B, Cascarano G L, Cuocci C, Giacovazzo C, Mallamo M, Mazzone A and Polidori G 2015 J. Appl. Crystallogr. 48306

21. Sheldrick G M, SHELXL 971997 (Göttingen: University of Göttingen)

22. Levenson A S and Jordan V C 1997 Cancer Res. 57 3071

23. Denizot F and Lang R 1986 J. Immunol. Methods 89271

24. Ebrahimipour S Y, Sheikhshoaie I, Kautz A C, Ameri M, Pasban-Aliabadi H, Amiri Rudbari H, Bruno G and Janiak C 2015 Polyhedron 9399

25. Ebrahimipour S Y, Mohamadi M, Castro J, Mollania N, Amiri Rudbari H and Saccá A 2015 J. Coord. Chem. 68 632

26. Ebrahimipour S Y, Ranjabr Z R, Kermani E T, Amiri B P, Rudbari H A, Saccá A and Hoseinzade F 2015 Transition Met. Chem. 4039

27. Hathaway B J 1987 In Comprehensive Coordination Chemistry, Vol. 5 (eds.) G Ilkinson, R D Gillard and J A McCleverty (Oxford, UK: Pergamon Press)

28. Hathaway J 1972 J. Chem. Soc., Dalton Trans. 1196

29. Vyas K M, Jadeja R N, Patel D, Devkar R V and Gupta V K 2013 Polyhedron 65262 
30. Massoud S S, Mautner F Z, Abu-Youssef M A M and Shuaib N M 1999 Polyhedron 182061

31. Addison A W, Rao T N, Reedijk J, van Rijn J and Verschoor G C 1984 J. Chem. Soc, Dalton Trans. 7 1349

32. Vo N H, Xia Z, Hanko J, Yun T, Bloom S, Shen J, Koya K, Sun L and Chen S 2014 J. Inorg. Biochem. 13069

33. Özdemir U O, Aktan E, İlbiz F, Gündüzalp A B, Özbek N, Sarı M, Çelik O and Saydam S 2014 Inorg. Chim. Acta 423194

34. Lin J C, Yang S C, Hong T M, Yu S L, Shi Q, Wei L, Chen H Y, Yang P C and Lee K H 2009 J. Med. Chem. $\mathbf{5 2} 1903$
35. Bak Y, Kim H, Kang J W, Lee D H, Kim M S, Park Y S, Kim J H, Jung K Y, Lim Y and Hong J 2011 J. Agric. Food Chem. 5910286

36. Sigman D, Graham D, D'Aurora V and Stern A 1979 J. Biol. Chem. 25412269

37. Ramírez-Ramírez N, Mendoza-Díaz G and PedrazaReyes M 2003 Bioinorg. Chem. Appl. 125

38. Mukherjee S, Chowdhury S, Chattapadhyay A P and Bhattacharya A 2011 Inorg. Chim. Acta. 37340

39. Chen Y, Qin M Y, Wu J H, Wang L, Chao H, Ji L N and $\mathrm{Xu}$ A L 2013 Eur. J. Med. Chem. 70120

40. Desbois N, Pertuit D, Moretto J, Cachia C, Chauffert B and Bouyer F 2013 Eur. J. Med. Chem. 69719 